\title{
Natural science textbooks for the fourth grade and their text difficulty
}

\section{Lubiše Hrabí}

Envigogika 2012/VII/2- Recenzované články/ Reviewed Papers

Publikováno/Published 30. 09. 2012

DOI: http://dx.doi.org/10.14712/18023061.322

\section{Abstrakt}

$\checkmark$ příspěvku jsou obsaženy poznatky o hodnocení obtížnosti textu $v$ šesti současných českých učebnicích prírodovědy pro čtvrtý ročník základní školy. Analýzy textů byly provedeny modifikovanou metodou dle Průchy. Dosažené výsledky ukazují, že náročnost textu učebnic je odlišná (19 - 31 bodů). Knihy nakladatelství Alter, Fortuna a SPN jsou vhodné pro výuku ve čtvrtém ročníku.

\section{Abstract}

This paper presents findings regarding an assessment of the difficulty of text in six current Czech natural science textbooks for the fourth grade. The textual analysis was carried out according to a modified Prücha method. The results indicate that textual difficulty varies in the textbooks examined (19 - 31 points).

Textbooks published by the Alter, Fortuna and SPN publishing companies are suitable for teaching in the fourth grade.

\section{Klíčová slova}

Syntaktický faktor, sémantický faktor, obtížnost textu, učebnice př́rodovědy.

\section{Key words}

Syntactic factor, semantic factor, text difficulty, natural science textbooks. 


\section{Introduction}

In spite of the centrality of the book to education, and in spite of the attention that has been paid to aspects of the book (design, reading, bias in the text etc), the textbook itself and its use, seen in holistic terms, is an elusive component of schooling, at least from the viewpoint of conventional educational research and theory.

The textbook can be used as a window on the world, as well as a study of what knowledge is about in schools. A central question also entails what happens to knowledge when it is transformed from science and culture into the structure of a textbook. In the following, we shall treat the textbook as a specific genre, different from other kinds of genres, like the literary text, the journalistic article, etc.

The study of textbook quality is a rather new but nonetheless very fruitful field for pedagogic research. If we speak about natural science textbooks, it is possible to mention that in our country natural science textbooks are published by six or more companies, and there are not many pedagogical research workers interested in comprehensive research of textbooks (Pluskal 1996). Some text analyses have been undertaken by these authors Hrabí (2005, 2008, 2009, 2010), Maňák - Knecht (2007), Mikk (2000), Olechowski (1995), Pluskal (1996), Průcha (1997), Shepardson - Pizzini (1991), Sikorová (2004), Stiner (1992), Vránová (2008). Such research is not very widespread these days.

That is why the aim of this paper is to provide the results of some Czech natural science textbook evaluations.

\section{Material and methods}

Evaluation of text difficulty was carried out on six natural science textbooks for the fourth grade. Natural science textbooks issued by the publishing companies Alter, Fortuna, Nová škola, Prodos, Scientia and SPN were examined. Ten samples of text from each textbook were examined according to a modified Prưcha method by random sample (Hrabí 2005). The method was modified because chapters are very short in natural science textbooks for the fourth or fifth grade. Each sample consisted of 100 or more words $(\Sigma N)$. The most important characteristics of text difficulty are values of syntactic and semantic factors. The first one shows us if the average length of a sentence and the number of words is high or not. The second characteristic documents the terminological complexity of the text. Overall text difficulty is achieved by calculating the sum of the values of the syntactic and semantic factors, these should be compared to the values from other books and then we can decide how difficult a particular text is. In evaluating a text, it is quite difficult to distinguish some terminological categories. The most important is to decide if a particular substantive is a common term or a scientific term. In our case, scientific terms are biological terms. The category of factual terms includes geographical terms, dates and abbreviations. Particular characteristics, their symbols, definitions, ways of calculation, are written as follows:

$$
\begin{aligned}
& \mathrm{T} \text { - text difficulty; } \mathrm{T}=\mathrm{T}_{\mathrm{s}}+\mathrm{T}_{\mathrm{p}} \text { (points), } \\
& \mathrm{T}_{\mathrm{s}}-\text { syntactic factor - syntactic level of text difficulty, } \\
& T_{s}=0,1 \times \bar{V} \times \bar{U} \text { (points), }
\end{aligned}
$$

$\bar{V}$ - average length of sentence - proportion of the number of words to the number of sentences,

$\bar{U}$ - syntactic complexity of sentence - proportion of the number of words to the number of regular verbs, 
$T_{p}$ - semantic factor - degree of terminological difficulty of the text,

$$
\begin{gathered}
T_{p}=100 \times \frac{\sum P}{\sum N} \times \frac{\sum P_{1}+2 \sum P_{2}+3 \sum P_{3}}{\sum N} \text { (points) } \\
\bar{V}=\frac{\sum N}{\sum V} \text { (number of words) } \\
\bar{U}=\frac{\sum N}{\sum U} \text { (number of words) }
\end{gathered}
$$

$\Sigma N$ - number of words

$\Sigma \mathrm{V}$ - number of sentences

$\Sigma U$ - number of regular verbs

$\Sigma \mathrm{P}$ - number of substantives

$\Sigma P_{1}$ - number of common terms

$\Sigma \mathrm{P}_{2}$ - number of scientific terms

$\Sigma P_{3}-$ number of factual terms

- coefficient of density of scientific and factual information - proportion of the number of scientific and factual terms to the number of words (\%)

$$
h=100 \times \frac{\sum P_{2}+\sum P_{3}}{\sum P}-\text { coefficient of density of scientific and factual information - }
$$

proportion of the number of scientific and factual terms to the number of substantives (\%)

\section{Results and discussion}

The most important characteristics of text difficulty are written in Table 1.

The total number of analysed words varies from 1030 to 1063 in the natural science textbooks studied. They form from 93 to 115 sentences. This large difference is caused by the authors who created these natural science textbooks. The average length of one sentence is about $9-11$ words. The syntactic complexity of the average sentence achieves only 7 words and is shorter than in textbooks for the fourth grade (Hrabí 2010). The total number of common terms is quite different in the textbooks studied and ranges from 53 to 108 terms. This shows that some authors of textbooks use common substantives very often and others use them very rarely. Therefore, texts with many common substantives are easier for pupils to understand. The total number of scientific terms is very different and varies from 196 to 282. This very high range of biological terms in the textbooks examined demonstrates that particular texts could be understood differently by pupils (Průcha 1997). 
The number of factual terms ranges from 1 to 21 . It shows that some authors of textbooks use geographical terms, dates or abbreviations differently. But this category of terms is not difficult for a pupil's comprehension (Pluskal 1996). The values of the syntactic factor range from 6.41 to 8.08 points. The lowest value is characteristic for the textbook issued by the SPN publishing company. It shows that this book contains short sentences and has a low complexity of one sentence. Semantic factor values vary from 11.23 to 24.16 points. This very large range of semantic factor values shows that the textbooks of different publishing companies have various numbers of common terms, scientific terms and factual terms. According to this study, the textbook of the Scientia publishing company does not contain many substantives in any sentences. In contrast, the textbook of the Nová škola publishing company has many substantives in a single sentence.

The coefficients of density of scientific and factual information (i) range from $19.13 \%$ to $28.43 \%$, and the coefficients of scientific and factual information (h) fluctuate between $70.61 \%$ and $84.73 \%$. This shows that the natural science textbooks investigated contain a various density of scientific and factual information. The results of the evaluation of text difficulty demonstrate that the natural science textbooks studied have texts of varying difficulty - from 19 to 31 points. These results demonstrate that the textbooks studied have different values of an average length of sentence, syntactic complexity of sentences, and semantic factor values are influenced by various proportions of scientific terminological categories. The results should be compared to results for the fifth grade and analysed with the same method (Hrabí 2010). Textbooks for fifth grade are more balanced from the point of view of text difficulty than textbooks for the fourth grade.

The main components of the text difficulty are provided in Graph 1. Syntactic factor values (Ts) show the different complexity of sentences. Semantic factor values of (Tp) are very different in the textbooks studied. The lowest value is characteristic of the textbook issued by the Scientia publishing company and the highest value was recorded in the textbook issued by the Nová škola publishing company.

Table 1 Main characteristics of text difficulty in natural science textbooks for the fourth grade (studied a modified Průcha method)

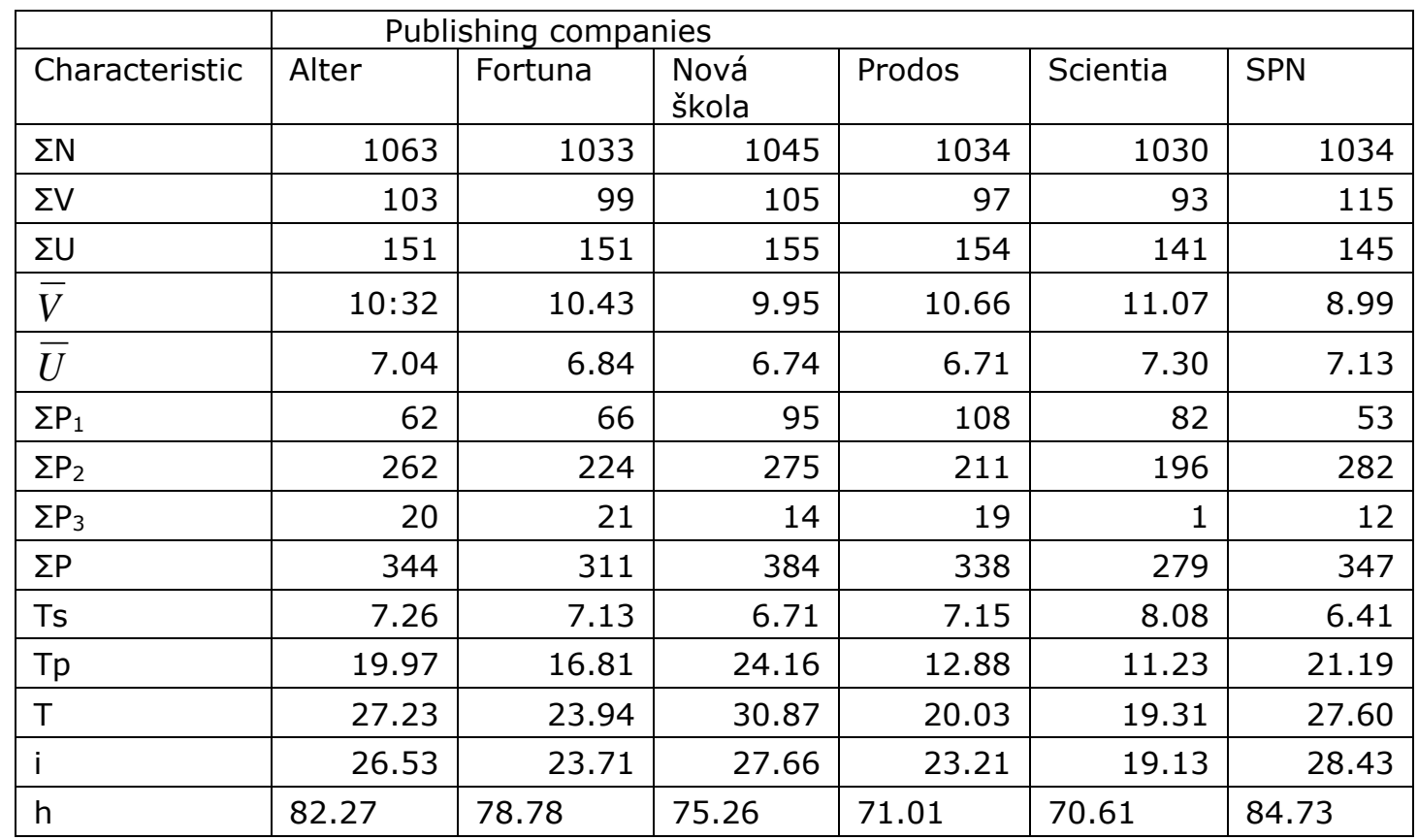


Graph 1 Values of the text difficulty (T), syntactic factor (Ts) and semantic factor (Tp) in textbooks investigated for the fourth grade (studied by a modified Prücha method)

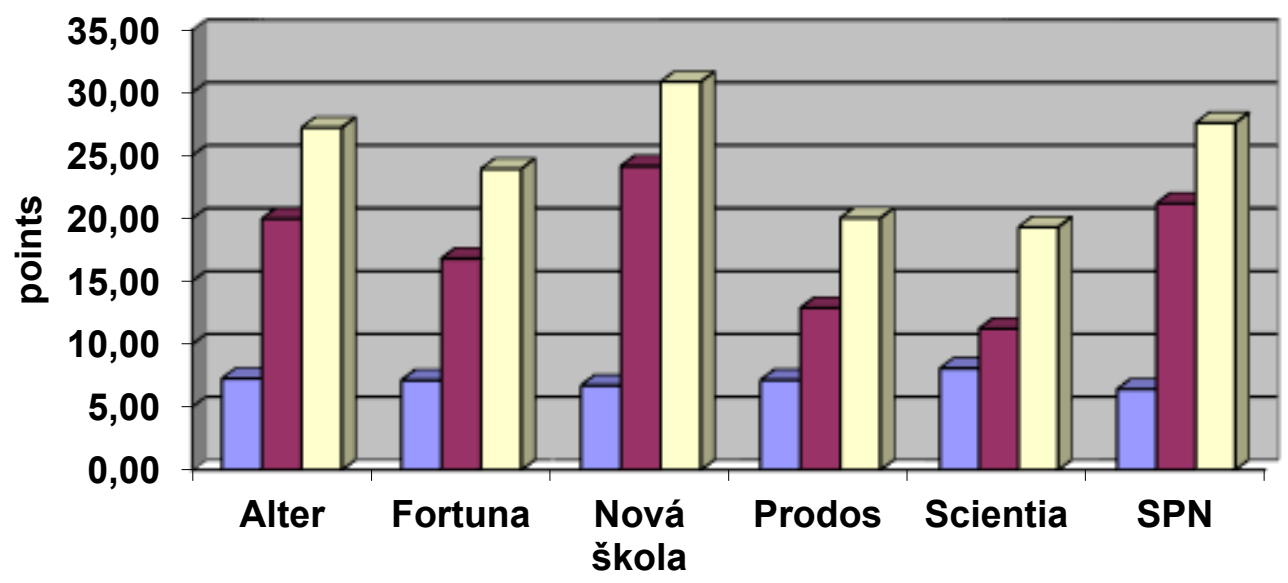

\section{Conclusion}

This paper contains findings regarding evaluation of text difficulty in six natural science textbooks for the fourth grade. The results indicate that the difficulty of text is very different in the textbooks studied (19 - 31 points). The results should be compared to the results of other texts analysed by the same method. The text difficulty is the lowest in the case of the textbook issued by the Scientia publishing company, and the highest in the textbook issued by the Nová škola publishing company. The average value of text difficulty is 24.83 points. These results indicate that the above textbooks are not suitable for teaching. They show that the Scientia textbook has a very low syntactic complexity of sentences and a low number of biological terms. That is why it cannot be recommended for teaching in the fourth grade, while the Nová škola textbook has very high scores for these characteristics and is not suitable in the common educational process, either. According to this study, the results show that teachers can use the natural science textbooks published by Alter, Fortuna and SPN for teaching in the fourth grade.

\section{Literature}

- Hrabí, L. (2005). Hodnocení obtížnosti učebnic př́rodopisu. Habilitační práce. Olomouc: UP Olomouc.

- Hrabí, L. (2008) K problematice obtížnosti učebnic. In KNECHT, P., JANÍK, T. et al. (Ed.), Učebnice z pohledu pedagogického výzkumu (pp. 177-187). Brno: Paido.

- Hrabí, L. (2009). Biology textbooks of Fraus publishing company and their text difficulty. ePedagogium, 9(1), 31-37.

- Hrabí, L. (2010). . e-Pedagogium, 10(1), 28-33.

- Maňák, J., \& Knecht, P. (2007). Hodnocení učebnic. Brno: Paido.

- Mikk, J. (2000). Textbook: Research and Writting. Frankfurt a. M.: Peter Lang. , 426,

- Olechowski, R. (1995). Aspekte der Schulbuchforschung. Erziehung und Unterricht. Schulbuchforschung.erziehung Und Unterricht, 145(4), 266-270. 
- $\quad$ Pluskal, M. (1996). Teorie tvorby učebnic a metody jejich hodnocení. Olomouc.

- Průcha, J. (1997). Moderní pedagogika. Praha: Portál.

- Shepardson, D., \& Pizzini, E. (1991). Questioning levels of junior high school science textbooks and their implication forlearning textual information. Science Education, 23(9), 50-52.

- Sikorová, Z. (2004). Výběr učebnic na základních a středních školách. Ostrava: PdF OU.

- Stiner, A. (1992). Science textbooks and science teaching: from logic to evidence. ScienceEducation. , 76(1), 1-16.

- Vránová, O. (2008). The most frequent types of tasks in Czech biology textbooks. .

- e-Pedagogium, (2008). . , 8(1), 78-83.

- Jurčák, J. et al., (1996). Př́rodověda pro 4. ročník. Olomouc: Prodos.

- Kholová, H., Hísek, K., Knotková, L., KNOTEK, J., (1995). Př́rodověda 4. Praha: Alter.

- Komanová, E., ZIEgleR, V., (1996). Př́rodověda 4. Praha: Scientia.

- Přírodověda pro 4. ročník (2001). Praha: Fortuna.

- Mladá, J., \& Podroužek, L. et al. 2003, (2003). Přírodověda pro 4. ročník. Praha: SPN.

- Novotný, A., \& et al., (1999). Př́rodověda 4. Praha: Alter.

- Štiková, V. (2007). Přírodověda 4. Brno: Nová škola.

\section{Evaluated textbooks}

- JURČÁK, J. et al. 1996. Prírodověda pro 4. ročník. Olomouc: Prodos, 71 p.

- KHOlOVÁ, H., HÍSEK, K., KNOTKOVÁ, L., KNOTEK, J. 1995. Př́rodověda 4, Praha: Alter, vol. 1. $58 \mathrm{p}$.

- $\quad$ KOMAnOVÁ, E., ZIEgleR, V. 1996. Př́rodověda 4. Praha: Scientia, 125 p.

- $\quad$ KVASNIČKOVÁ, D., FRONĚK, J. 2001. Př́rodověda pro 4. ročník. Praha: Fortuna, 93 p.

- $\quad$ MLADÁ, J., PODROUŽEK, L. et al. 2003. Př́rodověda pro 4. ročník. Praha: SPN, 79 p.

- NOvOtnÝ, A.. et al. 1999. Př́rodověda 4. Praha: Alter, vol. 2. 54 p.

- S ŠTikOVÁ, V. 2007. Př́rodověda 4. Brno: Nová škola, 56 p.

Libuše Hrabí, Doc., RNDr., Ph.D.

Profesní zaměření - didaktika př́rodopisu a biologie, obecná botanika, genetika Působiště - Katedra biologie PdF UP, Purkrabská 2, 77140 Olomouc ,e-mail = libuse.hrabi@upol.cz

Poznámka: Článek vznikl za finanční podpory specifického vysokoškolského výzkumu studentské grantové soutěže číslo PdF_2011_033 na UPOL. 
Časopis Envigogika vydává Centrum pro otázky životního prostředí UK. Vývoj časopisu je podpořen projektem OP VK Mezioborová sit́ udržitelného rozvoje.

Více najdete na internetových stránkách projektu mosur.czp.cuni.cz
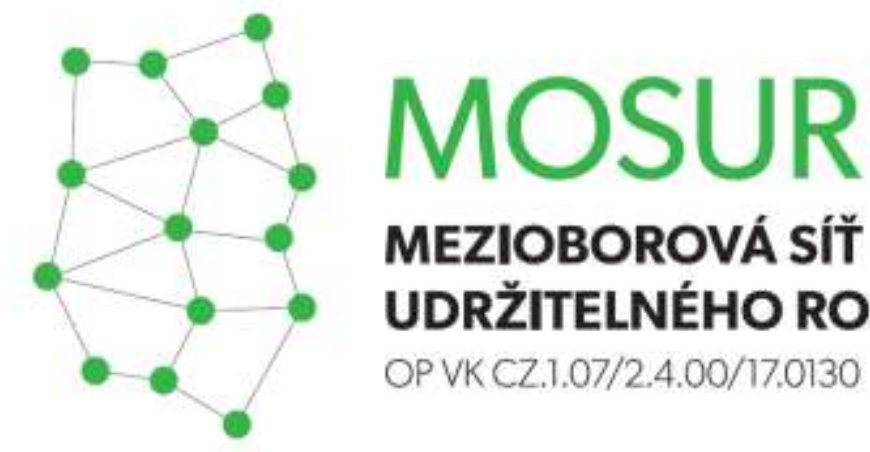

\section{MEZIOBOROVÁ SÍT}

UDRŽITELNÉHO ROZVOJE

OP VK CZ.1.07/2.4.00/17.0130
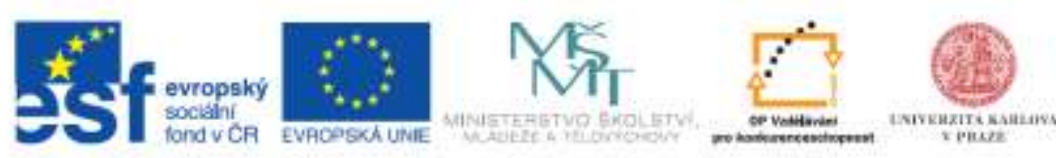

INVESTICE DO ROZVOJE VZDELAVANI 